\title{
Microbial iron uptake in the naturally fertilized waters in the vicinity of the Kerguelen Islands: phytoplankton-bacteria interactions
}

\author{
M. Fourquez ${ }^{1,2,3}$, I. Obernosterer ${ }^{2,3}$, D. M. Davies ${ }^{4,5}$, T. W. Trull ${ }^{4,5}$, and S. Blain ${ }^{2,3}$ \\ ${ }^{1}$ Institute for Marine and Antarctic Studies, University of Tasmania, Hobart 7001, Australia \\ ${ }^{2}$ Sorbonne Universités, UPMC Univ Paris 06, UMR 7621, Laboratoire d'Océanographie Microbienne, \\ Observatoire Océanologique, 66650 Banyuls/mer, France \\ ${ }^{3}$ CNRS, UMR 7621, Laboratoire d'Océanographie Microbienne, Observatoire Océanologique, 66650 Banyuls/mer, France \\ ${ }^{4}$ CSIRO Oceans and Climate Flagship, Hobart 7001, Australia \\ ${ }^{5}$ Antarctic Climate and Ecosystems Cooperative Research Centre, Hobart 7001, Australia
}

Correspondence to: M. Fourquez (marion.fourquez@utas.edu.au)

Received: 7 October 2014 - Published in Biogeosciences Discuss.: 24 October 2014

Revised: 4 February 2015 - Accepted: 11 February 2015 - Published: 23 March 2015

\begin{abstract}
Iron (Fe) uptake by the microbial community and the contribution of three different size fractions was determined during spring phytoplankton blooms in the naturally Fe-fertilized area off the Kerguelen Islands (KEOPS2). Total Fe uptake in surface waters was on average $34 \pm$ $6 \mathrm{pmolFe} \mathrm{L}^{-1} \mathrm{~d}^{-1}$, and microplankton (> $25 \mu \mathrm{m}$ size fraction; 40-69\%) and pico-nanoplankton $(0.8-25 \mu \mathrm{m}$ size fraction; $29-59 \%)$ were the main contributors. The contribution of heterotrophic bacteria $(0.2-0.8 \mu \mathrm{m}$ size fraction) to total $\mathrm{Fe}$ uptake was low at all stations (1-2\%). Iron uptake rates normalized to carbon biomass were highest for pico-nanoplankton above the Kerguelen Plateau and for microplankton in the downstream plume. We also investigated the potential competition between heterotrophic bacteria and phytoplankton for the access to $\mathrm{Fe}$. Bacterial $\mathrm{Fe}$ uptake rates normalized to carbon biomass were highest in incubations with bacteria alone, and dropped in incubations containing other components of the microbial community. Interestingly, the decrease in bacterial Fe uptake rate (up to 26fold) was most pronounced in incubations containing piconanoplankton and bacteria, while the bacterial $\mathrm{Fe}$ uptake was only reduced by 2 - to 8 -fold in incubations containing the whole community (bacteria + pico-nanoplankton + microplankton). In Fe-fertilized waters, the bacterial Fe uptake rates normalized to carbon biomass were positively correlated with primary production. Taken together, these results suggest that heterotrophic bacteria are outcompeted by
\end{abstract}

small-sized phytoplankton cells for the access to Fe during the spring bloom development, most likely due to the limitation by organic matter. We conclude that the Fe and carbon cycles are tightly coupled and driven by a complex interplay of competition and synergy between different members of the microbial community.

\section{Introduction}

Microorganisms in the ocean are characterized by widespread distributions, large abundances and high metabolic rate activities. Consequently they play a pivotal role in biogeochemical cycles of many elements (Arrigo, 2005; Madsen, 2011). Following the pioneering work of Martin (1990), a major achievement in the past decades has been the discovery of the tight but complex link between the carbon $(\mathrm{C})$ and iron $(\mathrm{Fe})$ biogeochemical cycles in the ocean. Thus, it is not surprising that microorganisms play a crucial role in the functioning and the coupling of both cycles. Autotrophs are a net $\mathrm{C}$ dioxide $\left(\mathrm{CO}_{2}\right)$ sink and heterotrophs are a net $\mathrm{CO}_{2}$ source, but both require $\mathrm{Fe}$ to process $\mathrm{C}$. Therefore, the balance between autotrophy and heterotrophy and ultimately the air-sea $\mathrm{CO}_{2}$ flux should be influenced by Fe availability for microorganisms. This issue is definitively 
critical in environments receiving low Fe supply, like the high-nutrient, low-chlorophyll regions (HNLC).

The role of heterotrophic bacteria has been far less studied than that of phytoplankton. However, essential data for the understanding of the responses of heterotrophic bacteria to $\mathrm{Fe}$ limitation have already been collected. Iron uptake rates, $\mathrm{Fe}$ cellular contents and $\mathrm{Fe}: \mathrm{C}$ ratios have been determined in various environments (Tortell et al., 1996; Maldonado et al., 2001; Sarthou et al., 2008). Culture experiments (Granger and Price, 1999; Fourquez et al., 2014) have elucidated some of the metabolic pathways affected by Fe limitation which may explain the changes observed in Fe-limited heterotrophic cells or communities. Additionally, the obligate requirement of $\mathrm{Fe}$ for heterotrophic bacteria and phytoplankton suggests that both organisms are competing for $\mathrm{Fe}$ acquisition. The competition between phytoplankton and bacteria was addressed experimentally (Mills et al., 2008) and conceptually (Litchman et al., 2004) for the access to nitrogen and phosphorus, but this issue has been rarely studied in the case of Fe (Boyd et al., 2012). Beside this possible pure competition, both autotrophic and heterotrophic microorganisms could also benefit from each other. Phytoplankton are a source of $\mathrm{C}$ for heterotrophic bacteria and the production of ligands by these latter could make $\mathrm{Fe}$ available for other microorganisms (Amin et al., 2009; Hassler et al., 2011a, b). The aim of our study was to further investigate the complex interactions between heterotrophic bacteria and phytoplankton with respect to the $\mathrm{C}$ and $\mathrm{Fe}$ cycling.

The Southern Ocean is the largest HNLC region in the world ocean. However, in several places, natural Fe fertilization sustains massive blooms (Blain et al., 2007; Pollard et al., 2009; Nielsdóttir et al., 2012). These naturally fertilized regions are exceptional laboratories to study interactions between the $\mathrm{Fe}$ and $\mathrm{C}$ cycling and the role played by microorganisms. The bloom located above the Kerguelen Plateau was investigated in detail during KEOPS1 (Kerguelen Ocean and Plateau compared Study, January-February 2005). KEOPS2 (October-November 2011) extended this study to early stages of the bloom and to new investigations in the blooms downstream the island. During KEOPS2 we determined the $\mathrm{Fe}$ uptake of the bulk microbial community and of different size fractions at stations characterized by a wide range of responses to $\mathrm{Fe}$ fertilization. We also conducted incubation experiments to specifically study the competition between heterotrophic bacteria and phytoplankton.

\section{Materials and methods}

\subsection{Site description}

This study was carried out as part of the KEOPS2 expedition that took place from 9 October to 29 November 2011, in the Indian sector of the Southern Ocean in the vicinity of the Kerguelen archipelago. For the present study, eight sta-

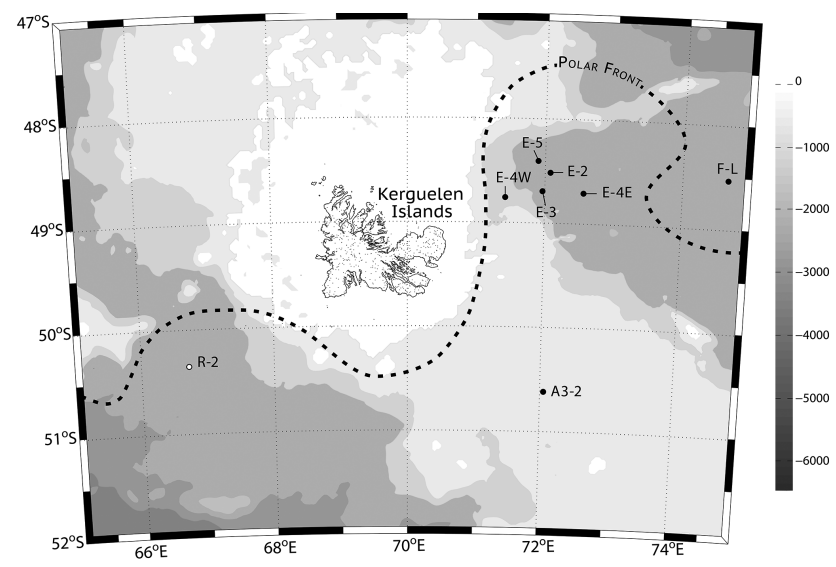

Figure 1. Map of the KEOPS2 study area showing the stations sampled for Fe uptake experiments. The dashed line represents the position of the polar front. The base map shows the bathymetry in metres.

tions were sampled (Fig. 1). Station R-2 is the reference station located outside the bloom, west of the Kerguelen Islands (Fig. 1). The E stations were located in a complex meander south of the polar front and sampled in a quasi-Lagrangian manner (d'Ovidio et al., 2015). An animation is given in the Supplement that shows the development of the bloom over the period of the cruise and position of the stations at the time of sampling (see the animation in the Supplement).

\subsection{Sampling and manipulation under trace metal clean conditions}

Seawater samples were collected with 10-L Niskin 1010X bottles set up on an autonomous model 1018 trace metal rosette especially adapted for trace metal work (General Oceanics Inc., USA; Bowie et al., 2014). Each Niskin bottle was acid-washed $(2 \% \mathrm{HCl})$ and rinsed with Milli-Q water before the rosette was deployed. All metal springs are Tefloncoated, and the crimps are made of aluminium. All samples were carefully manipulated in a clean container under a laminar flow hood (ISO class 5). Within less than $2 \mathrm{~h}$ after sample collection, the seawater was dispersed into $500 \mathrm{~mL}$ acidwashed polycarbonate (PC) bottles and the incubations performed as described below. The PC bottles were acid-washed $(10 \% \mathrm{HCl}$ Suprapur, Merck) three times, followed by three rinses with Milli-Q water, and were subsequently sterilized by microwaves $(5 \mathrm{~min}, 750 \mathrm{~W})$. The PC bottles were dried and stored under a laminar flow hood before being used. For the incubation experiments described below, seawater was collected in the surface mixed layer at one depth, and incubated at different levels of surface photosynthetically active radiation (PAR). Characteristics of the stations are given in Table 1. 
Table 1. Location, date, depth of sampling and main biogeochemical properties from studied stations. Experimental approach column refers to Fig. 2, with (a), (b) and (c) related to incubations including the whole community, pico-nanoplankton plus bacteria, and bacteria only, respectively.

\begin{tabular}{|c|c|c|c|c|c|c|c|c|c|c|c|}
\hline \multirow[t]{2}{*}{ Station } & \multirow[t]{2}{*}{$\begin{array}{l}\text { Latitude } \\
\text { S }\end{array}$} & \multirow[t]{2}{*}{$\begin{array}{l}\text { Longitude } \\
\text { E }\end{array}$} & \multirow{2}{*}{$\begin{array}{c}\text { Date of } \\
\text { sampling } \\
\text { (dd/mm/yyyy) }\end{array}$} & \multirow{2}{*}{$\begin{array}{c}\text { Depth of } \\
\text { sampling } \\
\text { (m) }\end{array}$} & \multirow{2}{*}{$\begin{array}{l}\text { SST } \\
\left({ }^{\circ} \mathrm{C}\right)\end{array}$} & $\mathrm{NO}_{3}^{-}+\mathrm{NO}_{2}^{-\mathrm{a}}$ & $\mathrm{PO}_{4}^{3-\mathrm{a}}$ & $\mathrm{Si}(\mathrm{OH})_{4}{ }^{\mathrm{b}}$ & \multirow{2}{*}{$\begin{array}{c}\text { Chl } a^{\mathrm{c}} \\
\left(\mu \mathrm{gL}^{-1}\right)\end{array}$} & \multirow{2}{*}{$\begin{array}{c}\mathrm{DFe}^{\mathrm{d}} \\
\left(\mathrm{nmolL}^{-1}\right)\end{array}$} & \multirow[t]{2}{*}{$\begin{array}{l}\text { Experimental } \\
\text { approach }^{\mathrm{e}}\end{array}$} \\
\hline & & & & & & \multicolumn{3}{|c|}{$\left(\mu \mathrm{molL}^{-1}\right)$} & & & \\
\hline \multicolumn{12}{|c|}{ HNLC reference } \\
\hline $\mathrm{R}-2$ & -50.3590 & 66.7170 & $26 / 10 / 2011$ & 40 & 2.3 & 25.4 & 1.81 & 12.1 & 0.32 & 0.09 & (b), (c) \\
\hline \multicolumn{12}{|c|}{ Kerguelen Plateau } \\
\hline A3-2 & -50.6240 & 72.0560 & $17 / 11 / 2011$ & 20 & 2.3 & 25.2 & 1.75 & 18.4 & 1.6 & 0.18 & (a), (b), (c) \\
\hline \multicolumn{12}{|c|}{ Polar front } \\
\hline F-L & -48.5320 & 74.6590 & $07 / 11 / 2011$ & 20 & 4.3 & 18.5 & 0.900 & 6.45 & 2.8 & 0.26 & (b) \\
\hline \multicolumn{12}{|c|}{ Downstream plume } \\
\hline E-2 & -48.5230 & 72.0770 & $01 / 11 / 2011$ & 20 & 3.0 & 26.6 & 1.74 & 14.5 & 0.42 & 0.08 & (b) \\
\hline E-3 & -48.7020 & 71.9670 & $02 / 11 / 2011$ & 20 & 3.1 & 25.4 & 1.78 & 15.1 & 0.079 & 0.38 & (b) \\
\hline E-4W & -48.7650 & 71.4250 & $12 / 11 / 2011$ & 20 & 2.7 & 25.3 & 1.74 & 17.5 & 0.56 & 0.20 & (b), (c) \\
\hline E-4E & -48.7150 & 72.5630 & $13 / 11 / 2011$ & 20 & 3.2 & 24.3 & 1.62 & 12.1 & 1.3 & 0.19 & (a), (b), (c) \\
\hline E-5 & -48.4120 & 71.9000 & $19 / 11 / 2011$ & 20 & 3.3 & 25.0 & 1.73 & 11.5 & 1.1 & 0.06 & (a), (b), (c) \\
\hline
\end{tabular}

${ }^{\mathrm{a}}$ From Blain et al. (2015). ${ }^{\mathrm{b}}$ From Closset et al. (2014). ${ }^{\mathrm{c}}$ From Lasbleiz et al. (2014). ${ }^{\mathrm{d}}$ From Quéroué et al. (2015). ${ }^{\mathrm{e}}$ For details see Fig. 2 and Sect. 2.3.

\subsection{Iron uptake experiments}

Three types of incubation experiments were performed (Fig. 2). In one set of experiments (Fig. 2a), $300 \mathrm{~mL}$ of unfiltered seawater was amended with $\mathrm{Fe}$ as ${ }^{55} \mathrm{FeCl}_{3}(0.2 \mathrm{nM}$ final concentration of ${ }^{55} \mathrm{Fe}$, specific activity $1.83 \times 10^{3} \mathrm{Ci} \mathrm{mol}^{-1}$, Perkin Elmer); incubated for $24 \mathrm{~h}$ at 75,25 and $1 \%$ surface PAR; and then sequentially filtered through 0.8 and $0.2 \mu \mathrm{m}$ pore size nitrocellulose filters ( $47 \mathrm{~mm}$ diameter, Nuclepore). These incubations, performed at station A3-2, E-4E and E-5, provided measurements of the Fe uptake of the bulk community based on the sum of the radioactivity measured on the 0.8 and $0.2 \mu \mathrm{m}$ filters. The uptake of Fe by heterotrophic bacteria incubated with the whole community (bacteria + piconanoplankton + microplankton) was also determined from these incubations. In a second set of experiments (Fig. 2b), seawater $(300 \mathrm{~mL})$ was pre-filtered through a $25 \mu \mathrm{m}$ mesh before $0.2 \mathrm{nM}{ }^{55} \mathrm{Fe}$ (final concentration) was added. This porosity was chosen to exclude microplankton by retaining them on the $25 \mu \mathrm{m}$ mesh. Following incubation at 75, 45, $25,16,4$ and $1 \%$ of surface PAR, the seawater was sequentially filtered through 0.8 and $0.2 \mu \mathrm{m}$ filters. The uptake of Fe by pico-nanoplankton $(0.8-25 \mu \mathrm{m}$, Supplement table), and that of heterotrophic bacteria $(0.2-0.8 \mu \mathrm{m})$ in the presence of pico-nanoplankton only, was derived from these incubations. At the stations where these two types of experiments were performed concurrently (stations A3-2, E-4E and E-5), the Fe uptake by microplankton was obtained by the difference between the bulk Fe uptake (Fig. 2a) and the sum of the Fe uptake by pico-nanoplankton and heterotrophic bacteria (Fig. 2b). In a third set of experiments, $300 \mathrm{~mL}$ seawater was $0.8 \mu \mathrm{m}$ pre-filtered prior to the addition of $0.2 \mathrm{nM}$ ${ }^{55} \mathrm{Fe}$ (final concentration) to exclude both microplankton and pico-nanoplankton from the incubation. Following the $24 \mathrm{~h}$ incubation at $1 \%$ PAR level, the seawater was filtered on a
$0.2 \mu \mathrm{m}$ filter (Fig. 2c). Based on this type of incubation, we determined the Fe uptake by heterotrophic bacteria in incubations with bacteria alone. This experiment was performed at stations A3-2, E-4E, E-5, E-4W and R-2.

For all the incubations, bottles were maintained at in situ surface temperature (Table 1) in on-deck incubators supplied continuously with surface seawater. The incubators were equipped with a combination of nickel screens (LEE Filters, UK) simulating light intensities from 75 to $1 \%$. Incubations were conducted from dawn to dawn.

Additionally, to determine whether a steady state had been achieved after $24 \mathrm{~h}$ of incubation time, we performed a separate set of experiments where $\mathrm{Fe}$ uptake by bacteria and bacterial cell abundance was followed over $24,72,96 \mathrm{~h}$ and 1week incubation time. Due to the low bacterial $\mathrm{Fe}$ uptake rates determined over $24 \mathrm{~h}$, we did not perform any time series over shorter incubation times. Our results are therefore based on the assumption of linearity in bacterial Fe uptakes rates over the $24 \mathrm{~h}$ incubation period.

\subsection{Determination of intracellular ${ }^{55} \mathrm{Fe}$}

A first step for the assessment of the ${ }^{55} \mathrm{Fe}$ uptake was the removal of ${ }^{55} \mathrm{Fe}$ not incorporated by cells, using a washing solution. Following filtration, the filters were washed with $6 \mathrm{~mL}$ of Ti-citrate-EDTA solution (Hudson and Morel, 1989; Tang and Morel, 2006) for $2 \mathrm{~min}$ and subsequently rinsed three times with $5 \mathrm{~mL}$ of $0.2 \mu \mathrm{m}$ filtered seawater for $1 \mathrm{~min}$ (Fourquez et al., 2012). The filters were placed into plastic vials and $10 \mathrm{~mL}$ of the scintillation cocktail Filtercount (Perkin Elmer) was added. Vials were agitated for $24 \mathrm{~h}$ before the radioactivity was counted with the Tricarb ${ }^{\circledR}$ scintillation counter. Total radioactivity on the filter after correction for background represents intracellular ${ }^{55} \mathrm{Fe}$. For each station, controls were obtained with $300 \mathrm{~mL}$ of microwave- 


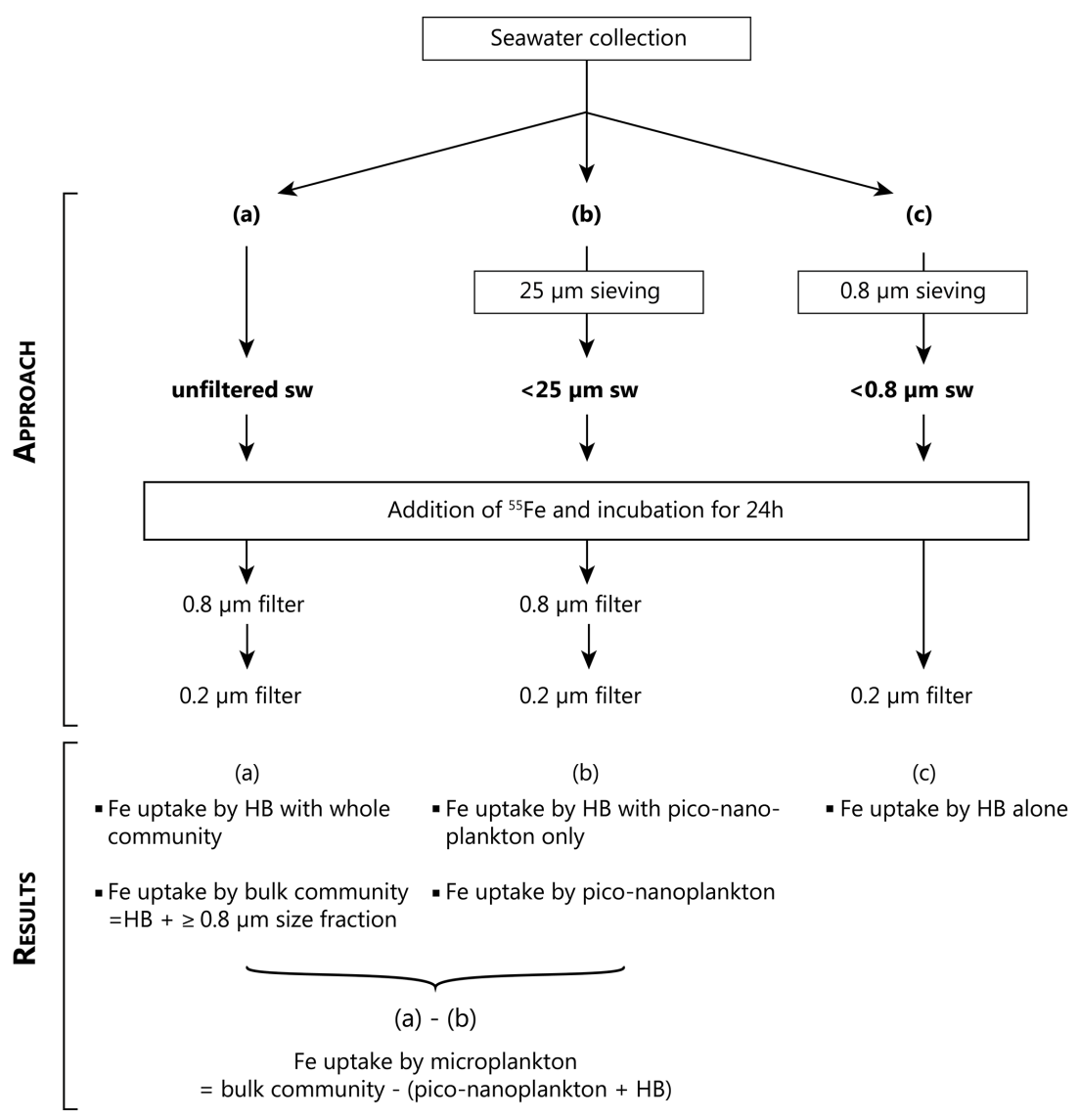

Figure 2. Schematic representation of experiments to determine Fe uptake by heterotrophic bacteria $(0.2-0.8 \mu \mathrm{m})$, pico-nanoplankton $(0.8-$ $25 \mu \mathrm{m})$ and microplankton $(>25 \mu \mathrm{m})$ during the KEOPS2 cruise (sw: seawater; HB: heterotrophic bacteria)).

sterilized seawater $(750 \mathrm{~W}$ for $5 \mathrm{~min}$, repeated three times) incubated with the same amount of ${ }^{55} \mathrm{Fe}$ and treated in the same way as the live treatments. The radioactivity determined on these filters was considered as background and is based on the amount of ${ }^{55} \mathrm{Fe}$ adsorbed but not incorporated by cells. Abiotic adsorption of ${ }^{55} \mathrm{Fe}$ onto cells could be influenced by microwave irradiation if cell structures are altered by the treatment. For technical reasons, we could not use formalin to fix the cells at each station, but we performed a series of tests to compare fixation by formalin and by microwave. The background radioactivity of the formalin-killed seawater was similar to that of the microwave-sterilized seawater, validating our control. We performed one control per station maintained for $24 \mathrm{~h}$ at $75 \%$ PAR in the on-deck incubator. The radioactivity measured on the control filters was subtracted from the respective live treatments in all experiments.

To determine the most appropriate concentration of the radioisotope to be added, different amounts of ${ }^{55} \mathrm{Fe}$ were tested: $0.2,0.4,0.8,1$ and $2 \mathrm{nM}$ of unchelated ${ }^{55} \mathrm{Fe}$ (as ${ }^{55} \mathrm{FeCl}_{3}$, final concentrations of ${ }^{55} \mathrm{Fe}$ ). We determined that the concentration of $0.2 \mathrm{nM}{ }^{55} \mathrm{Fe}$ was the most appropriate as it minimizes changes in dissolved $\mathrm{Fe}(\mathrm{DFe})$ concentration and it still allows for detection of the incorporated radioactivity by scintillation counting (for $300 \mathrm{~mL}$ of seawater filtered). We also observed that adding more than $0.8 \mathrm{nM}$ of ${ }^{55} \mathrm{Fe}$ (final concentration) stimulates the Fe uptake by microorganisms (pico-nanoplankton and bacteria; data not shown). Using our preferred small addition of $0.2 \mathrm{nM}$, consumption of ${ }^{55} \mathrm{Fe}$ during our incubations was negligible $(1-4 \%$ of total ${ }^{55} \mathrm{Fe}$ added), and the consumption of the corresponding total DFe even smaller.

The Fe uptake rate (molFe $\mathrm{L}^{-1} \mathrm{~d}^{-1}$ ), noted $\rho \mathrm{Fe}$ (all symbols are listed in Table 2), was calculated with the following equations:

$\rho \mathrm{Fe}=\frac{A \cdot{ }^{55} \mathrm{Fe} \text { on filter }}{t \cdot V}$,

with

$A=\frac{\text { mol }{ }^{55} \mathrm{Fe} \text { added }+ \text { mol DFe in situ }}{\text { mol }^{55} \mathrm{Fe} \text { added }}$,

${ }^{55} \mathrm{Fe}$ on filter $=\frac{(\mathrm{dpm} \text { on filter sample }- \text { dpm on filter control })}{{ }^{55} \mathrm{Fe} \text { specific activity }}$,

where $V$ is the volume filtered, $t$ the incubation time, and dpm disintegrations per minute. 
Table 2. List of abbreviations used.

\begin{tabular}{|c|c|}
\hline Symbols & Explanation \\
\hline$\rho \mathrm{Fe}$ & Total iron uptake \\
\hline$\rho \mathrm{Fe}_{\text {bact }}^{\text {alone }}$ & Bacterial iron uptake determined in incubations with bacterial cells alone (size fraction $<0.8 \mu \mathrm{m}$, Fig. $2 \mathrm{c}$ ) \\
\hline$\rho \mathrm{Fe}_{\mathrm{bact}}^{<25 \mu \mathrm{m}}$ & Bacterial iron uptake determined in incubations with pico- and nanoplankton only (size fraction $<25 \mu \mathrm{m}$, Fig. $2 \mathrm{~b}$ ) \\
\hline$\rho \mathrm{Fe}_{\text {bact }}^{\text {whole }}$ & Bacterial iron uptake determined in incubations with the whole community (unfiltered seawater, Fig. 2a) \\
\hline$\rho \mathrm{Fe}: \mathrm{POC}$ & Total iron uptake normalized to particulate organic carbon \\
\hline$(\rho \mathrm{Fe}: \mathrm{POC})_{\text {bact }}^{\text {alone }}$ & $\begin{array}{l}\text { Bacterial iron uptake determined in incubations with bacterial cells alone (size fraction }<0.8 \mu \mathrm{m} \text {, Fig. } 2 \mathrm{c} \text { ) } \\
\text { normalized to particulate organic carbon }\end{array}$ \\
\hline$(\rho \mathrm{Fe}: \mathrm{POC})_{\mathrm{bact}}^{<25 \mu \mathrm{m}}$ & $\begin{array}{l}\text { Bacterial iron uptake determined in incubations with pico- and nanoplankton only (size fraction }<25 \mu \mathrm{m} \text {, Fig. } 2 \mathrm{~b} \text { ), } \\
\text { normalized to particulate organic carbon }\end{array}$ \\
\hline$(\rho \mathrm{Fe}: \mathrm{POC})_{\text {bact }}^{\text {whole }}$ & $\begin{array}{l}\text { Bacterial iron uptake determined in incubations with the whole community (unfiltered seawater, Fig. 2a) } \\
\text { normalized to particulate organic carbon }\end{array}$ \\
\hline
\end{tabular}

\subsection{Enumeration of heterotrophic bacteria}

Subsamples for cell enumeration were taken at the start and end of the incubations. To enumerate heterotrophic bacteria, $2 \mathrm{~mL}$ samples were fixed with glutaraldehyde ( $1 \%$ final concentration), incubated for $1 \mathrm{~h}$ at $4{ }^{\circ} \mathrm{C}$, and stored at $-80^{\circ} \mathrm{C}$ until processed (Obernosterer et al., 2008). Heterotrophic bacterial cell abundance was counted with a FASCCanto II BD flow cytometer (Becton, Dickinson). Heterotrophic bacterial cells were stained with SYBRGreen I (Marie et al., 1997) and enumerated for $1 \mathrm{~min}$ at a rate of $30 \mu \mathrm{L} \mathrm{min}^{-1}$. The machine drift was tested using calibration beads $(3 \mu \mathrm{m})$. Specific bacterial growth rates were calculated from the slope of log-linear regression between the start and the end of the incubation.

\subsection{Carbon content of different microbial size fractions}

The cellular $\mathrm{C}$ content for heterotrophic bacteria was estimated to be $12.4 \mathrm{fgCcell}^{-1}$ as reported by Fukuda et al. (1998). The C contents for pico-nanoplankton and microplankton were estimated from particulate organic carbon (POC) measured in surface seawater $(<1000 \mu \mathrm{m})$ on $300,210,50,20,5$ and $1 \mu \mathrm{m}$ pore-size filters (see Trull et al., 2015). We assumed the total $\mathrm{C}$ biomass (representative of the bulk community) to be the sum of all these fractions plus the estimated $\mathrm{C}$ biomass for heterotrophic bacteria. For pico-nanoplankton we assumed the sum of the POC concentrations on the 1 and $5 \mu \mathrm{m}$ filters, corresponding to the 1$20 \mu \mathrm{m}$ size fraction, to be representative of this community. To obtain the $\mathrm{C}$ biomass for microplankton, we subtracted the POC concentration of the $0.2-20 \mu \mathrm{m}$ size fraction of the total $\mathrm{C}$ biomass.

\section{Results}

\subsection{Bulk iron uptake rates and contribution of different size fractions}

The Fe uptake rate $(\rho \mathrm{Fe})$ for the bulk community, determined from incubations of unfiltered seawater (Fig. 2a), was measured at stations A3-2, E-4E and E-5, and the volumetric and integrated values are presented on Tables 3 and 4, respectively. The integration of $\rho \mathrm{Fe}$ over the euphotic layer reveals highest values at station E-5 $\left(1.74 \mu \mathrm{molFe} \mathrm{m}^{-2} \mathrm{~d}^{-1}\right)$, decreasing to $1.12 \mu \mathrm{molFe} \mathrm{m}^{-2} \mathrm{~d}^{-1}$ at station A3-2 and to $0.86 \mu \mathrm{molFe} \mathrm{m}^{-2} \mathrm{~d}^{-1}$ at station E-4E (Table 4). At these three stations the contribution of heterotrophic bacteria to total $\rho \mathrm{Fe}$ was less than $2 \%$ corresponding to a mean daily integrated uptake of $0.018 \pm 0.005 \mu \mathrm{mol} \mathrm{m}{ }^{-2} \mathrm{~d}^{-1}$ (Table 4). The contribution of the two other size fractions was stationdependent (Fig. 3). At station E-4E, microplankton and piconanoplankton had almost equal contributions to total integrated $\rho \mathrm{Fe}$ (53 and $46 \%$, respectively). At station A32 , microplankton and pico-nanoplankton accounted for 40 and $59 \%$ of total integrated $\rho \mathrm{Fe}$, respectively. The contribution of microplankton was the highest at station E-5 (69\% of total integrated $\rho \mathrm{Fe}$ ), whereas the contribution of piconanoplankton was the lowest ( $29 \%$ of total integrated $\rho \mathrm{Fe}$ ) at this site.

To account for differences in the biomass among stations, we normalized $\rho \mathrm{Fe}$ to the concentration of POC of the microplankton and pico-nanoplankton size classes and to the estimated cellular $\mathrm{C}$ content for bacteria, and both ratios are referred to $\rho \mathrm{Fe}$ : POC (Table 3). For the bulk community, a trend similar to $\rho \mathrm{Fe}$ was observed, with the highest $\rho \mathrm{Fe}$ : POC at station E-5 $\left(5.3 \pm 1.1 \mu \mathrm{mol} \mathrm{Fe} \mathrm{d}^{-1} \mathrm{molC}^{-1}\right.$; $n=3$, mean $\pm 1 \mathrm{SD}$ of the three PAR levels), decreasing to $3.0 \pm 1.0$ and $2.5 \pm 0.4 \mu \mathrm{molFe} \mathrm{d}^{-1} \mathrm{molC}^{-1} \quad(n=$ 3 , mean $\pm 1 \mathrm{SD}$ ) at stations $\mathrm{A} 3-2$ and $\mathrm{E}-4 \mathrm{E}$, respectively. Because this variability in $\rho \mathrm{Fe}: \mathrm{POC}$ could in part reflect differences in $\rho \mathrm{Fe}$ and $\mathrm{C}$ biomass contribution of 
Table 3. Iron uptake rates ( $\rho \mathrm{Fe})$, carbon biomass (POC), and C-normalized Fe uptake rates ( $\rho \mathrm{Fe}$ : POC) of the bulk community and the three size fractions for incubations conducted at 75,25 and $1 \%$ of the photosynthetically active radiation (PAR, \% of surface PAR) on unfiltered seawater (see text and Fig. 2a for details).

\begin{tabular}{|c|c|c|c|c|c|c|c|c|c|c|}
\hline & \multirow[t]{2}{*}{$\begin{array}{c}\text { PAR } \\
(\%)\end{array}$} & \multicolumn{3}{|c|}{$\begin{array}{c}\text { Fe uptake rate } \\
\left(\mathrm{pmolFe}^{-1} \mathrm{~d}^{-1}\right)\end{array}$} & \multicolumn{3}{|c|}{$\begin{array}{c}\text { C biomass } \\
\left(\mu \mathrm{molCL} \mathrm{L}^{-1}\right)\end{array}$} & \multicolumn{3}{|c|}{$\begin{array}{l}\text { C-normalized Fe uptake rate } \\
\left(\mu \mathrm{molFed}{ }^{-1} \mathrm{molC}^{-1}\right)\end{array}$} \\
\hline & & A3-2 & E-4E & E-5 & A3-2 & E-4E & E-5 & A3-2 & E-4E & E-5 \\
\hline \multirow{3}{*}{$\begin{array}{l}\text { Bulk community } \\
(>0.2 \mu \mathrm{m})^{*}\end{array}$} & 75 & 33.2 & 28.1 & 39.5 & 10.2 & 10.1 & 6.2 & 3.26 & 2.78 & 6.33 \\
\hline & 25 & 19.0 & 26.5 & 32.7 & 10.2 & 10.4 & 6.2 & 1.86 & 2.56 & 5.27 \\
\hline & 1 & 39.8 & 22.6 & 26.3 & 10.3 & 11.1 & 6.2 & 3.87 & 2.03 & 4.23 \\
\hline \multirow{3}{*}{$\begin{array}{l}\text { Microplankton } \\
(>25 \mu \mathrm{m})\end{array}$} & 75 & 15.5 & 13.4 & 33.7 & 6.9 & 5.4 & 2.9 & 2.25 & 2.50 & 11.56 \\
\hline & 25 & 5.1 & 13.2 & 22.4 & 6.8 & 5.3 & 2.9 & 0.75 & 2.47 & 7.68 \\
\hline & 1 & 17.9 & 13.5 & 15.3 & 6.9 & 5.4 & 2.9 & 2.60 & 2.52 & 5.25 \\
\hline \multirow{3}{*}{$\begin{array}{l}\text { Pico-nanoplankton } \\
(0.8-25 \mu \mathrm{m})\end{array}$} & 75 & 17.7 & 14.3 & 5.3 & 3.0 & 12.0 & 2.7 & 5.84 & 1.19 & 1.93 \\
\hline & 25 & 13.3 & 12.8 & 9.9 & 3.0 & 12.0 & 2.7 & 4.39 & 1.07 & 3.61 \\
\hline & 1 & 21.3 & 8.8 & 10.1 & 3.0 & 12.1 & 2.8 & 7.03 & 0.73 & 0.39 \\
\hline \multirow{3}{*}{$\begin{array}{l}\text { Heterotrophic bacteria } \\
(0.2-0.8 \mu \mathrm{m})\end{array}$} & 75 & 0.07 & 0.30 & 0.46 & 0.3 & 0.7 & 0.6 & 0.21 & 0.45 & 0.80 \\
\hline & 25 & 0.60 & 0.43 & 0.41 & 0.4 & 0.8 & 0.6 & 1.69 & 0.52 & 0.73 \\
\hline & 1 & 0.57 & 0.34 & 0.39 & 0.4 & 0.7 & 0.6 & 1.37 & 0.49 & 0.66 \\
\hline
\end{tabular}

* $\rho \mathrm{Fe}$ : POC for bulk community was calculated as the sum of the iron uptake rates of the three size fractions divided by the sum of particulate organic carbon of each size fraction.

organisms, we also considered $\rho \mathrm{Fe}$ : POC for the different size classes. At station E-5 microplankton revealed the highest $\rho \mathrm{Fe}$ : POC ratios $\left(5.25-11.56 \mu \mathrm{molFe}^{-1} \mathrm{molC}^{-1}\right)$, while at station A3-2 pico-nanoplankton was highest (4.39$7.03 \mu \mathrm{molFe} \mathrm{d}^{-1} \mathrm{molC}^{-1}$ ). At station E-5, at $75 \%$ of PAR, microplankton revealed the highest $\rho \mathrm{Fe}: \mathrm{POC}$ of all observed values. This is driven by the $\mathrm{Fe}$ uptake rate because $\mathrm{C}$ biomass was almost equally partitioned between microplankton (47\% of total C biomass) and pico-nanoplankton (44\% of total C biomass). Heterotrophic bacterial $\rho \mathrm{Fe}: \mathrm{POC}$ was quite homogeneous in incubations at different PAR levels at stations E-4E $\left(0.49 \pm 0.04 \mu \mathrm{molFe}^{-1} \mathrm{molC}^{-1}\right)$ and E-5 $\left(0.73 \pm 0.07 \mu \mathrm{molFe} \mathrm{d}^{-1} \mathrm{molC}^{-1}\right)$, but it presented high variability at station $\mathrm{A} 3-2$, ranging from 0.21 to $1.69 \mu \mathrm{molFe} \mathrm{d}^{-1} \mathrm{molC}^{-1}$ (Table 3). As expected, due to the low contribution of heterotrophic bacteria to total $\rho \mathrm{Fe}$, their $\mathrm{C}$-normalized $\rho \mathrm{Fe}$ was the lowest among the three size fractions.

\subsection{Heterotrophic bacterial iron uptake in the absence of phytoplankton}

To investigate whether heterotrophic bacteria compete with other members of the microbial community for the access to $\mathrm{Fe}$, the bacterial $\mathrm{Fe}$ uptake rates and the bacterial growth rates were also determined during incubations where microplankton and both microplankton and pico-nanoplankton were excluded (experiments (b) and (c), respectively, in Fig. 2). The bacterial Fe uptake rates were denoted $(\rho \mathrm{Fe})_{\text {bact }}^{\text {whole }}$ if incubated with the whole community; $(\rho \mathrm{Fe})_{\text {bact }}^{<25 \mu \mathrm{m}}$ if incubated with pico-nanoplankton only; and $(\rho \mathrm{Fe})_{\text {bact }}^{\text {alone }}$ refers to bac-

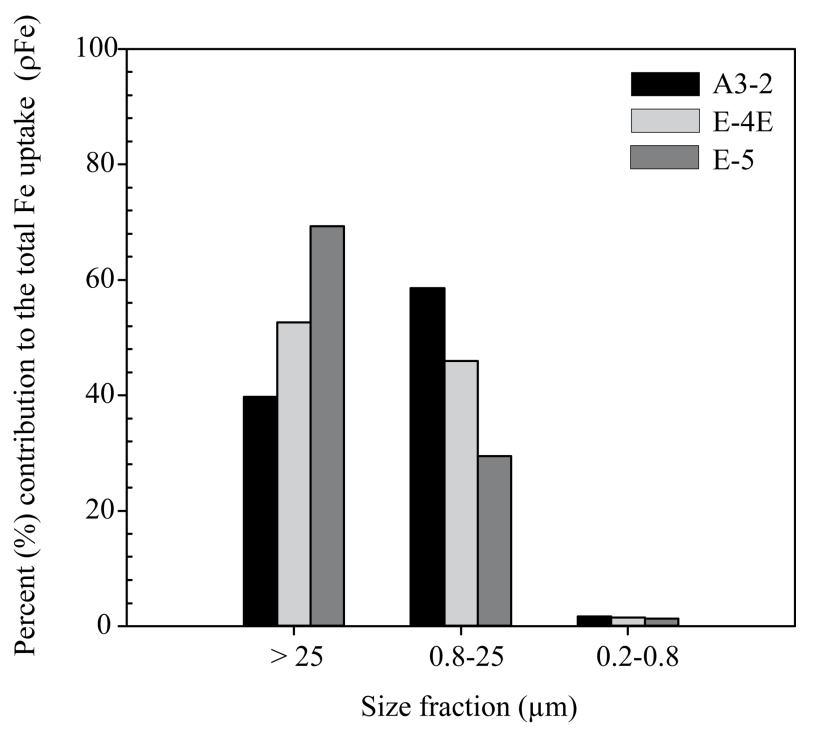

Figure 3. Relative contribution of different size fractions to total $\mathrm{Fe}$ uptake $(\rho \mathrm{Fe})$. The percent contribution was calculated from $\mathrm{Fe}$ uptake fluxes integrated over the euphotic layer at plateau (A3-2) and downstream plume (E-4E and E-5) stations.

terial Fe uptake rates measured when bacteria were incubated alone, with neither micro nor pico-nanoplankton. Incubations without microplankton were performed at six different light levels. At any given station, the variability of $(\rho \mathrm{Fe})_{\text {bact }}^{<25 \mu \mathrm{m}}$ determined at different light levels did not exceed a factor of 4 (Table 5). The unique noticeable excep- 
Table 4. Euphotic-layer-integrated Fe uptake of the bulk community and three size fractions. The depth of the euphotic layer is $39 \mathrm{~m}$ for A3-2, $80 \mathrm{~m}$ for E-4E and $41 \mathrm{~m}$ for E-5.

\begin{tabular}{|c|c|c|c|c|}
\hline \multirow[t]{2}{*}{ Station } & \multicolumn{4}{|c|}{$\begin{array}{l}\text { Euphotic-layer-integrated Fe uptake } \\
\qquad\left(\mu \mathrm{molFe} \mathrm{m}^{-2} \mathrm{~d}^{-1}\right)\end{array}$} \\
\hline & $\begin{array}{c}\text { Bulk } \\
\text { community } \\
(>0.2 \mu \mathrm{m})\end{array}$ & $\begin{array}{l}\text { Microplankton } \\
\qquad(>25 \mu \mathrm{m})\end{array}$ & $\begin{array}{l}\text { Pico-nanoplankton } \\
\qquad(0.8-25 \mu \mathrm{m})\end{array}$ & $\begin{array}{c}\text { Heterotrophic } \\
\text { bacteria } \\
(0.2-0.8 \mu \mathrm{m})\end{array}$ \\
\hline A3-2 & 1.12 & 0.44 & 0.66 & 0.019 \\
\hline E-4E & 0.86 & 0.45 & 0.40 & 0.013 \\
\hline E-5 & 1.74 & 1.21 & 0.51 & 0.023 \\
\hline
\end{tabular}

tion was station E-3, where $(\rho \mathrm{Fe})_{\text {bact }}^{<25 \mu \mathrm{m}}$ was about 2 orders of magnitude higher at $75 \%$ light level. To compare $(\rho \mathrm{Fe})_{\mathrm{bact}}^{<25 \mu \mathrm{m}}$ among stations, we integrated over the euphotic layer and the mixed layer depths. The outlier value at E-3 (at $75 \%$ PAR level) was not considered for the integration. The lowest depth-integrated values were observed at stations R-2 and E-5 (4.7 nmol Fe m ${ }^{-2} \mathrm{~d}^{-1}$ at both stations; mean of euphotic- and mixed-layer-integrated fluxes) and the highest values were observed at station E-3 (18.4 nmolFe m $\left.{ }^{-2} \mathrm{~d}^{-1}\right)$. Integrated Fe uptake did not show any clear temporal evolution for the stations at the quasi-Lagrangian time series E-2, E-3, E-4E and E-5 (Table 5).

The bacterial $\mathrm{Fe}$ uptake rate normalized to cellular $\mathrm{C}$ content was also determined in the incubations where microplankton was excluded (noted $(\rho \mathrm{Fe}: \mathrm{POC})_{\mathrm{bact}}^{<25 \mu \mathrm{m}}$ in Table 5). The high value of $(\rho \mathrm{Fe})_{\text {bact }}^{<25 \mu \mathrm{m}}$ measured at E-3 (at $75 \%$ PAR level) resulted in a high value of $(\rho \mathrm{Fe}: \text { POC })_{\text {bact }}^{<25 \mu \mathrm{m}}\left(21.4 \mu \mathrm{molFe} \mathrm{d}^{-1} \mathrm{molC}^{-1}\right)$ that is considered as an outlier. All other values ranged from 0.06 to $2.94 \mu \mathrm{molFe} \mathrm{d}^{-1} \mathrm{molC}^{-1}$, and they were 2 - to 8-fold lower than those in the corresponding incubations with the bulk

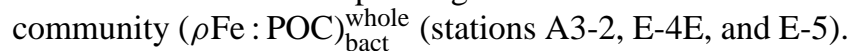
The normalization does not modify our general observation that there was no significant difference in the rates between the different light levels and between the different stations (two-tailed, unpaired Student's $t$ test, $p=0.27$ ). In consideration of this, the values at one given station are now treated as biological replicates.

At the three stations A3-2, E-4E and E-5 we compared the bacterial Fe uptake when bacteria were incubated with the whole community $\left((\rho \mathrm{Fe}: \mathrm{POC})_{\text {bact }}^{\text {whole }}\right)$ with that when incubated with pico-nanoplankton only $\left((\rho \mathrm{Fe}: \text { POC })_{\text {bact }}^{<25 \mu \mathrm{m}}\right)$ and that with bacteria alone $\left((\rho \mathrm{Fe}: \mathrm{POC})_{\text {bact }}^{\text {alone }}\right.$, Fig. 4$)$. For all stations, we found that bacterial $\mathrm{Fe}$ uptake was the highest in the absence of any other larger cells and the lowest when incubated with pico-nanoplankton only, with $(\rho \mathrm{Fe}: \mathrm{POC})_{\mathrm{bact}}^{\text {alone }}>(\rho \mathrm{Fe}: \mathrm{POC})_{\text {bact }}^{\text {whole }}>(\rho \mathrm{Fe}: \mathrm{POC})_{\text {bact }}^{<25 \mu \mathrm{m}}$. When bacteria were incubated with the entire microbial community, ( $\rho \mathrm{Fe}$ : POC $)_{\text {bact }}^{\text {whole }}$ was 2-8 times higher than in the incubations with pico-nanoplankton only $\left((\rho \mathrm{Fe}: \mathrm{POC})_{\mathrm{bact}}^{<25}\right)$, but still lower than when bacteria were incubated alone. Sim- ilarly to $(\rho \mathrm{Fe}: \mathrm{POC})_{\text {bact }}^{\text {alone }}$, bacterial growth rates were by 2 to 5 times higher when bacteria were incubated alone compared to incubations with pico-nanoplankton only (Fig. 4b).

\subsection{Growth rates and iron quota of heterotrophic bacteria}

In all the incubation experiments the abundance of heterotrophic bacteria was determined at the beginning and at the end of the incubation period. Assuming an exponential growth during the incubation provided an estimate of the growth rates. The lowest growth rate $\left(0.02 \mathrm{~d}^{-1}\right)$ was determined at the station R-2. For the other stations, the growth rate ranged from 0.12 (E-5) to $0.36 \mathrm{~d}^{-1}$ (E-3). We also measured $(\rho \mathrm{Fe}: \mathrm{POC})_{\text {bact }}^{\text {alone }}$ after $24,72,96 \mathrm{~h}$ and 7 days of incubation. The ( $\rho \mathrm{Fe}: \mathrm{POC})_{\text {bact }}^{\text {alone }}$ was similar after 24 and $96 \mathrm{~h}$ of incubation and decreased after 1 week of incubation (data not shown). This suggests that $24 \mathrm{~h}$ of incubation provides a measurement of steady-state Fe uptake rate. Thus, we derived the Fe quota for heterotrophic bacteria $\left(Q_{\mathrm{Fe}}\right)$ based on the equation $\rho=\mu Q_{\mathrm{Fe}}$ (Fig. 5). The Fe quota of heterotrophic bacteria was $4 \times 10^{-20}$ molFecell $^{-1}$ for stations R-2, E-5 and E-4W, and $8 \times 10^{-20}$ mol Fe cell ${ }^{-1}$ for station E-2, F-L, A3-2 and E-3.

\section{Discussion}

\subsection{The microbial iron demand}

In the vicinity of the Kerguelen Islands, natural Fe fertilization produces many blooms with different dynamics resulting from a combination of hydrodynamic and ecological drivers. These sites provide excellent opportunities to investigate the demand of different members of the microbial community for Fe, as well as how these members interact. During KEOPS2 we visited a variety of early spring blooms located above the Kerguelen Plateau and in offshore waters north and south of the polar front. We start our discussion by putting our results in the context of previous studies related to $\mathrm{Fe}$ uptake by the microbial community in the Southern Ocean.

In the early spring bloom located above the Kerguelen Plateau (station A3-2), the total Fe demand, defined here as the steady-state Fe uptake rate by the bulk community, was 33.2 pmol Fe L ${ }^{-1} \mathrm{~d}^{-1}$ in surface waters. This Fe demand is more than 6 times higher than that determined during KEOPS1 at the same site during the declining phase of the bloom $\left(5.3 \pm 1.2 \mathrm{pmol} \mathrm{L}^{-1} \mathrm{~d}^{-1}\right.$ for a mean value of A3-4 and A3-5, $50 \%$ of PAR; Sarthou et al., 2008). The Fe demand during KEOPS2 is also higher than that measured during the artificial Fe fertilization experiment SOIREE in the Antarctic zone. At about 13 days following the Fe addition, a time point which corresponded to the growing phase of the bloom, Bowie et al. (2001) determined an Fe demand of $11.9 \mathrm{pmol} \mathrm{L}^{-1} \mathrm{~d}^{-1}$ (mean mixed layer). The differences in the Fe demand between these three studies likely do not 
Table 5. Bacterial abundance, $\mathrm{C}$ biomass, Fe uptake rates, C-normalized Fe uptake rates and integrated Fe uptake (to the euphotic layer depth, Ze; to the mixed layer depth, MLD; average, avg). Values given in the columns (POC) $)_{\text {bact }}^{<25 \mu m},(\rho \mathrm{Fe})_{\text {bact }}^{<25 \mu \mathrm{m}}$ and $(\rho \mathrm{Fe}: \mathrm{POC})_{\text {bact }}^{<25 \mu \mathrm{m}}$ are relative to incubations with bacteria and pico-nanoplankton only. Values given in the columns (POC) $)_{\text {bact }}^{\text {whole }},(\rho \mathrm{Fe})_{\text {bact }}^{\text {whole }}$ and $(\rho \text { Fe }: \text { POC })_{\text {bact }}^{\text {whole }}$ are relative to incubations performed with the bulk community. Integrated values are calculated from incubations with bacteria and piconanoplankton only. nd: no data available. Cell numbers refer to the end of the incubation time $(24 \mathrm{~h})$.

\begin{tabular}{|c|c|c|c|c|c|c|c|c|c|c|c|c|}
\hline \multirow[t]{2}{*}{ Station } & \multirow[t]{2}{*}{$\begin{array}{c}\text { PAR } \\
\text { level } \\
(\%)\end{array}$} & \multicolumn{2}{|c|}{$\begin{array}{l}\text { Cell abundance } \\
\left(\times 10^{5} \text { cells } \mathrm{mL}^{-1}\right)\end{array}$} & \multicolumn{2}{|c|}{$\begin{array}{l}\text { Biomass } \\
\left(\mu \mathrm{gCL}^{-1}\right)\end{array}$} & \multicolumn{2}{|c|}{$\begin{array}{c}\text { Fe uptake rate } \\
\left(\mathrm{pmolFe}^{-1} \mathrm{~d}^{-1}\right)\end{array}$} & \multicolumn{2}{|c|}{$\begin{array}{l}\text { C-normalized Fe uptake rate } \\
\qquad\left(\mu \mathrm{molFed}{ }^{-1} \mathrm{molC}^{-1}\right)\end{array}$} & \multicolumn{3}{|c|}{$\begin{array}{c}\text { Integrated } \\
\text { Fe uptake } \\
\left(\mathrm{nmolFe} \mathrm{m}^{-2} \mathrm{~d}^{-1}\right)\end{array}$} \\
\hline & & $(\mathrm{POC})_{\text {bact }}^{<25 \mu \mathrm{m}}$ & $(\mathrm{POC})_{\text {bact }}^{\text {whole }}$ & $(\mathrm{POC})_{\mathrm{bact}}^{<25 \mu \mathrm{m}}$ & (POC) $)_{\text {bact }}^{\text {whole }}$ & $(\rho \mathrm{Fe})_{\text {bact }}^{<25 \mu \mathrm{m}}$ & $(\rho \mathrm{Fe})_{\text {bact }}^{\text {whole }}$ & $(\rho \mathrm{Fe}: \mathrm{POC})_{\mathrm{bact}}^{<25 \mu \mathrm{m}}$ & $(\rho \mathrm{Fe}: \mathrm{POC})_{\text {bact }}^{\text {whole }}$ & $\mathrm{Ze}$ & MLD & avg \\
\hline \multirow[t]{6}{*}{ E-4E } & 75 & 10.82 & 6.49 & 13.42 & 8.05 & 0.10 & 0.30 & 0.09 & 0.45 & & & \\
\hline & 45 & 6.74 & nd & 8.36 & nd & 0.19 & nd & 0.28 & nd & & & \\
\hline & 25 & 5.89 & 7.95 & 7.30 & 9.86 & 0.16 & 0.43 & 0.26 & 0.52 & & & \\
\hline & 16 & 6.89 & $\mathrm{nd}$ & 8.54 & nd & 0.40 & $\mathrm{nd}$ & 0.56 & nd & 9.7 & 12.8 & 11.3 \\
\hline & 4 & 7.80 & nd & 9.67 & nd & 0.23 & nd & 0.28 & nd & & & \\
\hline & 1 & 7.07 & 6.73 & 8.77 & 8.35 & 0.17 & 0.34 & 0.23 & 0.49 & & & \\
\hline \multirow[t]{6}{*}{ A3-2 } & 75 & nd & 3.50 & nd & 4.34 & 0.25 & 0.07 & nd & 0.21 & & & \\
\hline & 45 & 3.52 & nd & 4.36 & nd & 0.19 & nd & 0.51 & nd & & & \\
\hline & 25 & 3.75 & 3.45 & 4.65 & 4.28 & 0.10 & 0.60 & 0.26 & 1.69 & & & \\
\hline & 16 & 3.60 & nd & 4.46 & nd & 0.11 & nd & 0.30 & nd & 6.6 & 13.1 & 9.9 \\
\hline & 4 & 6.39 & nd & 7.92 & nd & 0.18 & nd & 0.27 & nd & & & \\
\hline & 1 & 3.78 & 4.01 & 4.69 & 4.97 & 0.16 & 0.57 & 0.40 & 1.37 & & & \\
\hline \multirow[t]{6}{*}{ E-5 } & 75 & 5.29 & 5.59 & 6.56 & 6.93 & 0.05 & 0.46 & 0.10 & 0.80 & & & \\
\hline & 45 & 5.55 & nd & 6.88 & nd & 0.06 & nd & 0.10 & nd & & & \\
\hline & 25 & 5.18 & 5.39 & 6.42 & 6.68 & 0.07 & 0.41 & 0.13 & 0.73 & & & \\
\hline & 16 & 5.45 & nd & 6.76 & nd & 0.06 & nd & 0.11 & nd & 5.2 & 4.2 & 4.7 \\
\hline & 4 & 6.66 & nd & 8.26 & nd & 0.13 & nd & 0.19 & nd & & & \\
\hline & 1 & 5.18 & 5.74 & 6.42 & 7.12 & 0.14 & 0.39 & 0.27 & 0.66 & & & \\
\hline \multirow[t]{6}{*}{ R-2 } & 75 & 2.84 & & 3.52 & & 0.07 & & 0.23 & & & & \\
\hline & 45 & 2.55 & & 3.16 & & 0.04 & & 0.14 & & & & \\
\hline & 25 & nd & & nd & & 0.00 & & $\mathrm{nd}$ & & & & \\
\hline & 16 & 2.90 & nd & 3.60 & nd & 0.25 & nd & 0.82 & nd & 4.4 & 5.0 & 4.7 \\
\hline & 4 & 2.85 & & 3.53 & & 0.05 & & 0.16 & & & & \\
\hline & 1 & 2.65 & & 3.29 & & 0.05 & & 0.19 & & & & \\
\hline \multirow[t]{6}{*}{ E-2 } & 75 & 4.30 & & 5.33 & & 0.07 & & 0.16 & & & & \\
\hline & 45 & 4.84 & & 6.00 & & 0.05 & & 0.09 & & & & \\
\hline & 25 & 5.48 & & 6.80 & & 0.06 & & 0.11 & & & & \\
\hline & 16 & nd & nd & nd & nd & 0.27 & nd & nd & nd & 5.8 & 5.8 & 5.8 \\
\hline & 4 & 5.68 & & 7.04 & & 0.05 & & 0.09 & & & & \\
\hline & 1 & 5.32 & & 6.60 & & nd & & 0.06 & & & & \\
\hline \multirow[t]{6}{*}{ E-3 } & 75 & 6.98 & & 8.66 & & 15.50 & & 21.4 & & & & \\
\hline & 45 & 5.83 & & 7.23 & & 0.25 & & 0.41 & & & & \\
\hline & 25 & 7.85 & & 9.73 & & 0.41 & & 0.51 & & & & \\
\hline & 16 & 6.96 & nd & 8.63 & nd & 0.25 & nd & 0.35 & nd & $20.0^{*}$ & $16.8^{*}$ & $18.4^{*}$ \\
\hline & 4 & 8.49 & & 10.53 & & 0.32 & & 0.36 & & & & \\
\hline & 1 & 7.27 & & 9.01 & & 0.29 & & 0.39 & & & & \\
\hline \multirow[t]{6}{*}{ F-L } & 75 & 5.23 & & 6.49 & & 0.84 & & 1.56 & & & & \\
\hline & 45 & 7.80 & & 9.67 & & 0.36 & & 0.45 & & & & \\
\hline & 25 & 7.80 & & 9.67 & & 0.58 & & 0.72 & & & & \\
\hline & 16 & 0.82 & nd & 1.02 & nd & 0.25 & nd & 2.94 & nd & 14.0 & 18.4 & 16.2 \\
\hline & 4 & 3.82 & & 4.74 & & 0.50 & & 1.26 & & & & \\
\hline & 1 & 22.36 & & 27.73 & & 0.49 & & 0.21 & & & & \\
\hline \multirow[t]{6}{*}{ E-4W } & 75 & 6.63 & & 8.22 & & 0.17 & & 0.25 & & & & \\
\hline & 45 & 6.70 & & 8.31 & & 0.21 & & 0.30 & & & & \\
\hline & 25 & 5.07 & & 6.29 & & 0.71 & & 1.36 & & & & \\
\hline & 16 & 19.40 & nd & 24.06 & nd & 0.23 & nd & 0.11 & nd & 13.8 & 16.6 & 15.2 \\
\hline & 4 & 13.90 & & 17.24 & & 0.21 & & 0.15 & & & & \\
\hline & 1 & 7.75 & & 9.61 & & 0.29 & & 0.35 & & & & \\
\hline
\end{tabular}

${ }^{*}$ Integrated value measured at $75 \%$ was excluded from the calculation.

result from differences in biomass, because POC concentrations in the surface mixed layer were similar between studies (10-12 $\mu \mathrm{M}$; Bowie et al., 2001; Sarthou et al., 2008; Trull et al., 2015).

For the KEOPS expeditions, different stages of the bloom provide a temporal framework to interpret these observations. However, this is not the case for the differences observed between KEOPS2 and SOIREE, which were both sampled during the early phase of a bloom, even if the blooms occurred at different seasons. Besides the seasonal differences, the location of the study could explain the variability in the $\mathrm{Fe}$ demand. Finally, the results of FeCycle provide a comparison with the Subantarctic Zone. The $\mathrm{Fe}$ demand determined for the steady-state microbial Fe budget was 26-101 pmol L ${ }^{-1} \mathrm{~d}^{-1}$ (Strzepek et al., 2005), thus at the upper bound or higher than during KEOPS2, although $\mathrm{C}$ biomasses were similar $(10.2 \mu \mathrm{M}$, average for the mixed layer; Strzepek et al., 2005). From all these comparisons it 

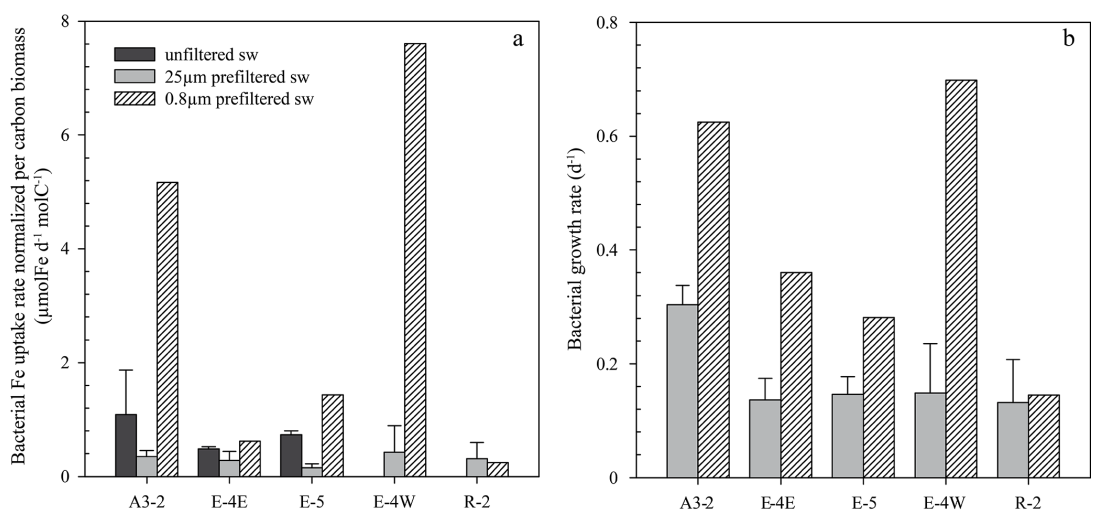

Figure 4. Bacterial Fe uptake normalized per $\mathrm{C}$ biomass (a) and bacterial growth rates (b) in incubations conducted with whole community $\left((\rho \mathrm{Fe}: \mathrm{POC})_{\mathrm{bact}}^{\text {whole }}\right.$, unfiltered seawater $)$, with pico-nanoplankton only $\left((\rho \mathrm{Fe}: \mathrm{POC})_{\text {bact }}^{<25 \mu \mathrm{m}}, 25 \mu \mathrm{m}\right.$ prefiltered seawater $)$, and when bacteria were incubated alone $\left((\rho \mathrm{Fe}: \mathrm{POC})_{\text {bact }}^{\text {alone }}, 0.8 \mu \mathrm{m}\right.$ prefiltered seawater $)$. As no significant effect of light on Fe uptake was observed for any station, we consider the values measured at the different levels of PAR as replicates. The bars for unfiltered seawater represent the average \pm 1 SD of the three light levels (75, 25 and $1 \%$ of surface PAR). The bars for $25 \mu \mathrm{m}$ prefiltered seawater represent the average \pm 1 SD of all the light levels ( $n=6$ for stations E-4E, E-5 and E- $4 \mathrm{~W} ; n=5$ for stations A3-2 and R-2).

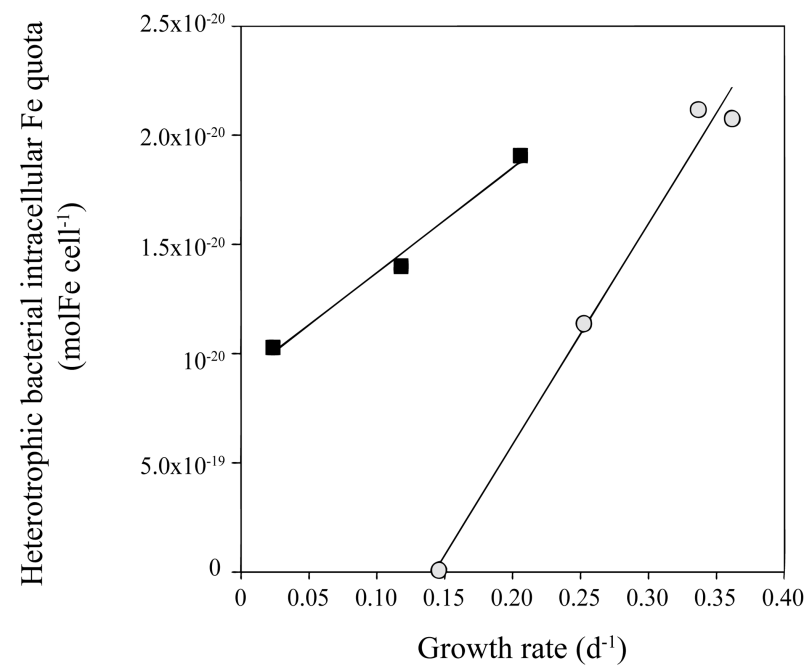

Figure 5. Relationship between the intracellular bacterial Fe quota and growth rate. Black squares: stations E-4W, E-5 and R-2; regression line $r^{2}=0.99, y=4.8 \times 10^{-14}+8.9 \times 10^{-15}$. Grey circles: stations E-2, E-3, A3-2 and F-L; regression line $r^{2}=0.99$, $y=10 \times 10^{-14}+1.4 \times 10^{-15}$. Calculations are based on bacterial Fe uptake and growth rates measured when bacteria were incubated with pico-nanoplankton only.

appears that, besides the variability driven by temporal or spatial factors, a plankton-based mechanistic explanation is certainly required for a better understanding of the observed differences.

Culture studies (Sunda and Huntsman, 1995, 1997; Strzepek and Harrison, 2004; Marchetti et al., 2009) and molecular approaches (Allen et al., 2008) have shown that there are multiple strategies for phytoplankton to deal with Fe limitation. The consequences are that bulk cell properties like the Fe uptake rate, the intracellular Fe concentration or the elemental $\mathrm{Fe}: \mathrm{C}$ ratio are species-dependent. However, the use of this basic knowledge to interpret field results is not straightforward. This is primarily due to the complexity of the natural phytoplankton community, but it is also obscured by possible regional differences as shown by Strzepek et al. (2012). Southern Ocean phytoplankton species responded to Fe-light acclimation differently than temperate species (Sunda and Huntsman, 1997; Strzepek et al., 2012). In the case of heterotrophic bacteria, culture studies (Granger and Price, 1999; Armstrong et al., 2004; Fourquez et al., 2014) and metagenomic analysis (Hopkinson and Barbeau, 2012; Toulza et al., 2012) have also provided foundations for our understanding of the responses of bacteria to Fe limitation but extrapolation to field observations face the same constraints as mentioned for phytoplankton.

A step forward to obtain some insight into the role of the community composition is to compare parameters in different size fractions. In Fe-fertilized systems in the Southern Ocean, the largest size fraction $(>25 \mu \mathrm{m})$, named microplankton, is almost entirely composed of diatoms. In the early spring bloom above the Kerguelen Plateau, this fraction contributed $40 \%$ of the total Fe uptake. This is substantially lower than during the declining phase of the bloom, when $62 \%$ of total Fe uptake was accounted for by microplankton (Sarthou et al., 2008). This decrease in the contribution of microplankton is consistent with the idea that the early phase of the bloom is dominated by a succession of rapidly growing diatoms of different sizes, and that larger, slow-growing and silicon-limited diatoms accumulate at the end of the season (Quéguiner, 2013). At the onset of the bloom above the plateau, pico-nanoplankton were the main contributor to $\mathrm{Fe}$ uptake $(69 \%)$, and this size fraction also revealed the highest $\mathrm{C}$-normalized Fe uptake rates. This fraction contains mainly 
small diatoms because non-diatom phytoplankton, as determined by flow cytometry, had a minor contribution to POC in this size fraction at station A3-2 $(7.4 \pm 0.4 \%, n=6)$. This suggests that the diatoms belonging to this size class are more competitive than larger cells for the conditions prevailing at this period of the season. The same observation holds for the FeCycle experiment in the Subantarctic where the Fe uptake was dominated by photosynthetic pico-nanoplankton during the early bloom (Strzepek et al., 2005; Boyd and Ellwood, 2010).

In addition to $\rho \mathrm{Fe}: \mathrm{POC}$, we have also calculated the $\mathrm{Fe}: \mathrm{C}$ uptake ratios based on in situ primary production measurements (Cavagna et al., 2014). In the Southern Ocean, $\mathrm{Fe}: \mathrm{C}$ uptake ratios (noted here $\rho \mathrm{Fe}: \rho \mathrm{C}$ ) reported in the literature range from $\sim 5$ to $50 \mu \mathrm{mol} \mathrm{Fe} \mathrm{molC} \mathrm{C}^{-1}$ (Sarthou et al., 2005; and references herein) and can reach up to $100 \mu \mathrm{molFe} \mathrm{molC}^{-1}$, as it was reported in some artificial Fe fertilizations (Boyd et al., 2000). During KEOPS2, the $\rho \mathrm{Fe}: \rho \mathrm{C}$ ranged from 3.7 (station A3-2) to $22.9 \mu \mathrm{molFe}$ molC $^{-1}$ (station E-5, Fig. 6). The values determined for the plateau station A3-2 (3.7-11 $\left.\mu \mathrm{molFe} \mathrm{molC} \mathrm{C}^{-1}\right)$ are similar to those reported for the declining phase of the bloom during KEOPS1 $\left(5.0 \pm 2.6 \mu \mathrm{molFe} \mathrm{mol} \mathrm{C}^{-1}\right.$, average for stations A3-1, A3-4 and A3-5; Sarthou et al., 2008). These $\rho \mathrm{Fe}: \rho \mathrm{C}$ ratios are also consistent with values measured during the two FeCycle studies where $\rho \mathrm{Fe}: \rho \mathrm{C}$ com-

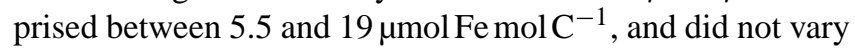
much with depth and over time (Strzepek et al., 2005; King et al., 2012). By contrast, at the stations located downstream of the plateau (E-4E and E-5) the $\rho \mathrm{Fe}: \rho \mathrm{C}$ values were overall higher than above the plateau (range from 10 to $22 \mu \mathrm{mol} \mathrm{Fe} \mathrm{molC}^{-1}$ ).

\subsection{Phytoplankton-bacteria competition for iron acquisition}

During KEOPS2, heterotrophic bacteria contributed less than $2 \%$ to the total $\mathrm{Fe}$ uptake $(\rho \mathrm{Fe})$. This is similar to the low contribution of heterotrophic bacteria of $1-5 \%$ to the total $\rho \mathrm{Fe}$ during FeCycle (Strzepek et al., 2005), but contrasts with observations from the subarctic Pacific, where heterotrophic bacteria dominated the Fe uptake (20-45\%; Tortell et al., 1996).

Heterotrophic bacterial $\mathrm{Fe}$ uptake was negatively affected by the presence of pico- to microplankton, suggesting competition between these members of the microbial community. Competition for the limiting nutrient is not unexpected, however, this issue has rarely been addressed in previous studies (Boyd et al., 2012). Bacterial and pico-nanoplanktonic cells could compete for nutrients as both have comparable metabolic rates and high capacities for resource acquisition (Massana and Logares, 2012). Our observation of the overall low contribution of heterotrophic bacteria to bulk Fe uptake suggests that the access to not only $\mathrm{Fe}$ but also organic $\mathrm{C}$ could have limited the bacterial response to natural Fe fer-

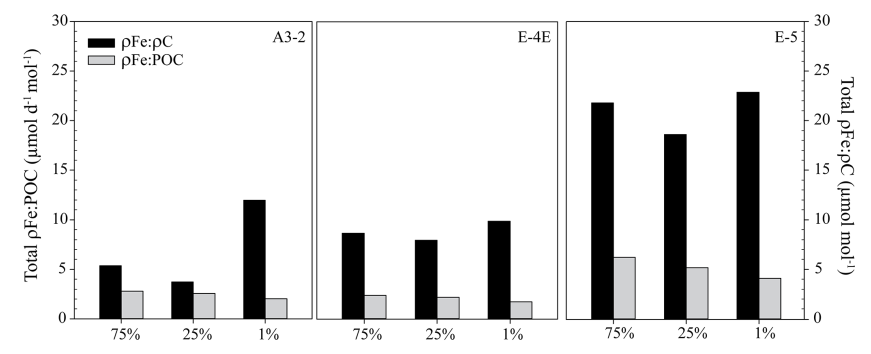

Figure 6. Comparison between total $\mathrm{Fe}: \mathrm{C}$ uptake ratios, noted $\rho \mathrm{Fe}: \rho \mathrm{C}$ (black bars), and Fe uptake by the bulk community normalized to $\mathrm{C}$ biomass noted $\rho \mathrm{Fe}$ : POC (grey bars) at three different surface PAR levels at stations A3-2 (plateau), E-4E and E-5 (plume).

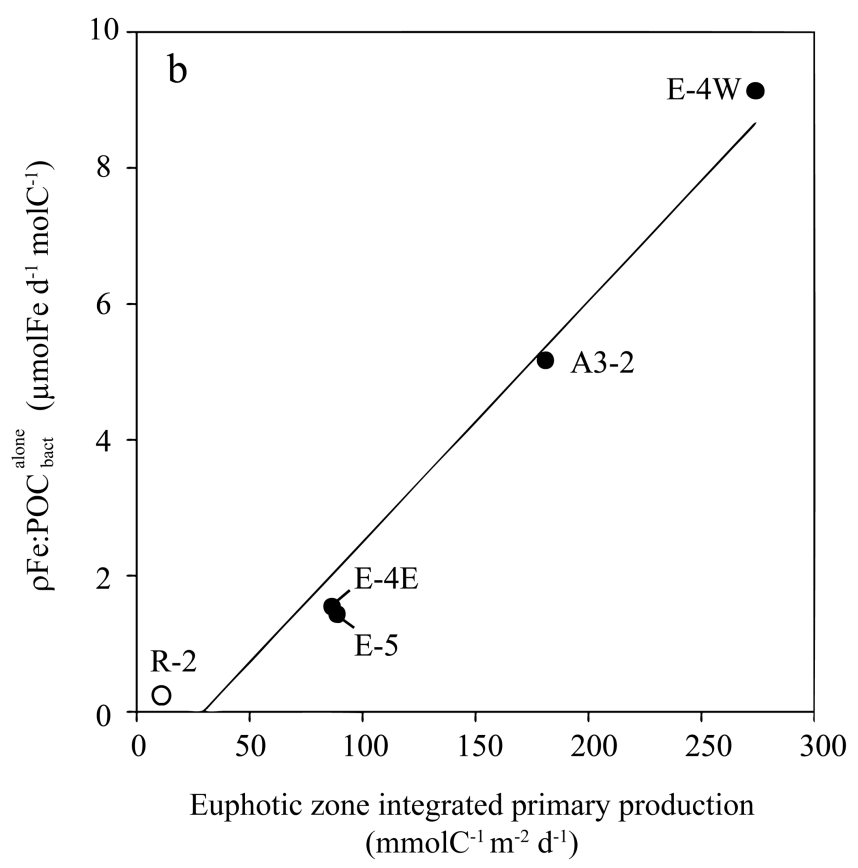

Figure 7. Relationship between the C-normalized bacterial Fe uptake $\left((\rho \mathrm{Fe}: \mathrm{POC})_{\text {bact }}^{\text {alone }}\right)$ and euphotic-zone-integrated primary production. The plotted line was obtained by least-squares regression $\left(r^{2}=0.97\right.$ with $\left.p=0.002\right)$. Empty symbol represents the reference station R-2 and filled symbols are for Fe-fertilized stations.

tilization. This idea is supported by the relation between the extent of stimulation of bacterial Fe uptake in fertilized waters and the increase in primary production (Fig. 7).

The bacterial $\mathrm{Fe}$ uptake rates were highest when measured in the absence of any larger cells and lowest in incubations where microplankton was excluded and bacteria were incubated with pico-nanoplankton only (Fig. 4a). This was the case for all stations where the experiment was conducted with $(\rho \mathrm{Fe}: \mathrm{POC})_{\text {bact }}^{\text {alone }} 5$ to 26 times higher than $(\rho \mathrm{Fe}: \mathrm{POC})_{\text {bact }}^{<25 \mu \mathrm{m}}$, except for the reference station $\mathrm{R}-2$. Considering that a higher degree of Fe limitation 
should result in an increased cellular Fe uptake rate raises the question of whether different degrees of Fe limitation of bacteria and pico-nanoplankton could explain the observed pattern. To evaluate the degree of $\mathrm{Fe}$ limitation, we compared bacterial and pico-nanoplankton $\mathrm{Fe}$ uptake rates (Table 6). Two clear features emerge. First, Fe uptake rates for bacteria $\left((\rho \mathrm{Fe}: \mathrm{POC})_{\text {bact }}^{\text {alone }}\right)$ and pico-nanoplankton $\left((\rho \mathrm{Fe}: \mathrm{POC})_{\text {pico-nano }}\right)$ are very similar for a given station, suggesting that they experienced a comparable degree of Fe limitation before the beginning of the incubation experiment. Second, the bacterial Fe uptake rates when incubated alone $\left((\rho \mathrm{Fe}: \mathrm{POC})_{\text {bact }}^{\text {alone }}\right)$ are higher in fertilized waters than at the HNLC site, suggesting that bacteria are not Fe-replete at the fertilized stations. The strong correlation between Cnormalized bacterial $\mathrm{Fe}$ uptake rates when incubated alone and primary production $\left(n=5, r^{2}=0.97\right.$ and $p=0.002$, Fig. 7) suggests that $C$ availability is the main driver of the Fe uptake potential of heterotrophic bacteria. Interestingly, no such correlation was obtained when bacteria were incubated with pico-nanoplankton only $\left(n=5, r^{2}=0.31\right.$ and $p=0.32$ ). These observations strongly suggest that for the stations located in Fe-fertilized regions, phytoplankton, and in particular pico-nanoplankton, competed with bacteria for $\mathrm{Fe}$ acquisition.

We propose two non-exclusive explanations for the observed positive correlation between these two parameters. First, the increase in primary production could be driven by an increase in $\mathrm{Fe}$ availability that may also benefit heterotrophic bacteria when competition with larger cells is alleviated. Second, the increase in primary production could result in an enhanced amount of phytoplankton-derived dissolved organic carbon (DOC), which in turn provides energy to synthesize more $\mathrm{Fe}$ transport molecules to cope with a certain degree of Fe limitation and also stimulates the bacterial Fe demand. In the absence of microplankton, the supply of phytoplankton-dissolved organic matter is likely to be lower, which could explain the strong decrease in bacterial Fe uptake rates in these incubations $(\rho \mathrm{Fe}: \text { POC })_{\text {bact }}^{<25 \mu \mathrm{m}}$. Both mechanisms are likely to occur, as independent experiments during KEOPS2 revealed that bacterial production was stimulated by both single additions of Fe and organic C (Obernosterer et al., 2014).

Dissolved organic carbon is undoubtedly one of the most important substrates provided by autotrophic phytoplankton cells to heterotrophic bacteria. The amount of DOC produced by phytoplankton during the bloom is likely to play a role in Fe demand by bacteria. Kirchman et al. (2000) suggested that low $\mathrm{Fe}$ availability leads to increase the $\mathrm{C}$ demand, and more recently Fourquez et al. (2014) provided some evidence that marine heterotrophic bacteria reallocate their inner resources to sustain this increase in the $\mathrm{C}$ demand when Fe-limited. Here, we also show that high $\mathrm{C}$ availability leads to an increase in $\mathrm{Fe}$ demand. Finally we note that the minimum values of $(\rho \mathrm{Fe}: \mathrm{POC})_{\text {bact }}^{<25 \mu \mathrm{m}}$ in compari-
Table 6. Carbon normalized Fe uptake rates for bacteria and piconanoplankton. Columns $(\rho \mathrm{Fe}: \mathrm{POC})_{\text {bact }}^{<25 \mu \mathrm{m}}$ and $(\rho \mathrm{Fe}: \mathrm{POC})_{\text {bact }}^{\text {alone }}$ are for bacteria incubated with pico-nanoplankton only and bacteria incubated alone, respectively. The column $(\rho \mathrm{Fe}: \mathrm{POC})_{\text {pico-nano }}$ stands for pico-nanoplankton. We note that this Fe uptake rate for pico-nanoplankton was measured during incubations with bacteria. Because pico-nanoplankton largely outcompeted bacteria, this rate,

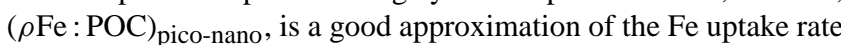
for pico-nanoplankton incubated alone. Values are from incubations performed at $1 \%$ of the PAR level.

\begin{tabular}{|c|c|c|c|}
\hline \multirow[t]{2}{*}{ Station } & \multicolumn{3}{|c|}{$\begin{array}{c}\rho \mathrm{Fe}: \text { POC } \\
\left(\mu \mathrm{molFe} \mathrm{d}^{-1} \mathrm{molC}^{-1}\right)\end{array}$} \\
\hline & $(\rho \mathrm{Fe}: \mathrm{POC})_{\mathrm{bact}}^{<25 \mu \mathrm{m}}$ & $(\rho \mathrm{Fe}: \mathrm{POC})_{\text {pico-nano }}$ & $(\rho \mathrm{Fe}: \mathrm{POC})_{\text {bact }}^{\text {alone }}$ \\
\hline A3-2 & 0.40 & 7.04 & 5.17 \\
\hline E4-E & 0.23 & 0.73 & 1.54 \\
\hline E-5 & 0.27 & 3.88 & 1.43 \\
\hline E4-W & 0.35 & 4.13 & 9.13 \\
\hline $\mathrm{R}-2$ & 0.19 & 0.14 & 0.24 \\
\hline
\end{tabular}

son to whole-community ( $\rho \mathrm{Fe}$ : POC $)_{\text {bact }}^{\text {whole }}$ and bacteria-only $(\rho \mathrm{Fe}: \mathrm{POC})_{\text {bact }}^{\text {alone }}$ incubations could arise via other microorganism allelopathic interaction mechanisms than competition for Fe. As such, further research is needed to examine interactions between pico-nanoplankton and bacteria across a wider range of conditions, i.e. including non-limiting $\mathrm{Fe}$ and $\mathrm{C}$ substrate levels.

Our observation that small diatoms were particularly competitive in removing $\mathrm{Fe}$ during the early stage of the spring phytoplankton bloom induced by natural Fe fertilization in the Southern Ocean suggests an intimate connection between heterotrophic bacteria and pico-nanoplankton. If this is the case, a progressive shift in the community composition from small to larger diatoms in the course of a bloom (Quéguiner, 2013) would affect the bacterial Fe uptake rates over time. This could partly explain why heterotrophic bacteria accounted for $17-27 \%$ of the overall Fe uptake in the late stage of the spring bloom (Sarthou et al., 2008), in contrast to 1$2 \%$ at the onset of the bloom. Together, these results demonstrate that the bacterial $\mathrm{Fe}$ and $\mathrm{C}$ metabolism are closely coupled, and that the structure of the microbial community has a marked effect on the extent of bacterially mediated Fe cycling.

\section{The Supplement related to this article is available online at doi:10.5194/bg-12-1893-2015-supplement.}


Acknowledgements. We would like to thank the captain, Bernard Lassiette; the chief scientist, Bernard Quéguiner; and the crew of $\mathrm{R} / \mathrm{V}$ Marion-Dufresne II for assistance on board. We gratefully acknowledge Emmanuel Laurenceau-Cornec for making the satellite chlorophyll animation available and Laurent Besnard for his assistance in creating Fig. 1. We thank the two anonymous reviewers, who helped to improve a previous version of the manuscript. This work was supported by the French research programme of INSU-CNRS LEFE-CYBER (Les enveloppes fluides et l'environnement - Cycles biogéochimiques, environnement et ressources), the French ANR (Agence Nationale de la Recherche, SIMI-6 programme, ANR-10-BLAN-0614), the French CNES (Centre National d'Etudes Spatiales) and the French Polar Institute IPEV (Institut Polaire Paul-Emile Victor).

Edited by: G. Herndl

\section{References}

Allen, A. E., Laroche, J., Maheswari, U., Lommer, M., Schauer, N., Lopez, P. J., Finazzi, G., Fernie, A. R., and Bowler, C.: Wholecell response of the pennate diatom Phaeodactylum tricornutum to iron starvation, P. Natl. Acad. Sci. USA, 105, 10438-10443, doi:10.1073/pnas.0711370105, 2008.

Amin, S. A., Green, D. H., Hart, M. C., Küpper, F. C., Sunda, W. G., Carrano, C. J., and Ku, F. C.: Photolysis of iron - siderophore chelates promotes bacterial - algal mutualism, P. Natl. Acad. Sci. USA, 106, 17071-17076, doi:10.1073/pnas.0905512106, 2009.

Armstrong, E., Granger, J., Mann, E. L., and Price, N. M.: Outer-membrane siderophore receptors of heterotrophic oceanic bacteria, Limnol. Oceanogr., 49, 579-587, doi:10.4319/lo.2004.49.2.0579, 2004.

Arrigo, K. R.: Molecular diversity and ecology of microbial plankton, Nature, 437, 343-348, doi:10.1038/nature04158, 2005.

Blain, S., Quéguiner, B., Armand, L., Belviso, S., Bombled, B., Bopp, L., Bowie, A., Brunet, C., Brussaard, C., Carlotti, F., Christaki, U., Corbière, A., Durand, I., Ebersbach, F., Fuda, J.L., Garcia, N., Gerringa, L., Griffiths, B., Guigue, C., Guillerm, C., Jacquet, S., Jeandel, C., Laan, P., Lefèvre, D., Lo Monaco, C., Malits, A., Mosseri, J., Obernosterer, I., Park, Y.-H., Picheral, M., Pondaven, P., Remenyi, T., Sandroni, V., Sarthou, G., Savoye, N., Scouarnec, L., Souhaut, M., Thuiller, D., Timmermans, K., Trull, T., Uitz, J., van Beek, P., Veldhuis, M., Vincent, D., Viollier, E., Vong, L., and Wagener, T.: Effect of natural iron fertilization on carbon sequestration in the Southern Ocean, Nature, 446, 10701074, doi:10.1038/nature05700, 2007.

Blain, S., Capparos, J., Guéneuguès, A., Obernosterer, I., and Oriol, L.: Distributions and stoichiometry of dissolved nitrogen and phosphorus in the iron-fertilized region near Kerguelen (Southern Ocean), Biogeosciences, 12, 623-635, doi:10.5194/bg-12623-2015, 2015.

Bowie, A. R., Maldonado, M. T., Frew, R. D., Croot, P. L., Achterberg, E. P., Mantoura, R. F. C., Worsfold, P. J., Law, C. S., and Boyd, P. W.: The fate of added iron during a mesoscale fertilisation experiment in the Southern Ocean, Deep-Sea Res. Pt. II, 48, 2703-2743, doi:10.1016/S0967-0645(01)00015-7, 2001.
Bowie, A. R., van der Merwe, P., Quéroué, F., Trull, T., Fourquez, M., Planchon, F., Sarthou, G., Chever, F., Townsend, A. T., Obernosterer, I., Sallée, J.-B., and Blain, S.: Iron budgets for three distinct biogeochemical sites around the Kerguelen archipelago (Southern Ocean) during the natural fertilisation experiment KEOPS-2, Biogeosciences Discuss., 11, 17861-17923, doi:10.5194/bgd-11-17861-2014, 2014.

Boyd, P. W. and Ellwood, M. J.: The biogeochemical cycle of iron in the ocean, Nat. Geosci., 3, 675-682, doi:10.1038/ngeo964, 2010.

Boyd, P. W., Watson, A. J., Law, C. S., Abraham, E. R., Trull, T., Murdoch, R., Bakker, D. C., Bowie, A. R., Buesseler, K. O., Chang, H., Charette, M., Croot, P., Downing, K., Frew, R., Gall, M., Hadfield, M., Hall, J., Harvey, M., Jameson, G., LaRoche, J., Liddicoat, M., Ling, R., Maldonado, M. T., McKay, R. M., Nodder, S., Pickmere, S., Pridmore, R., Rintoul, S., Safi, K., Sutton, P., Strzepek, R. F., Tanneberger, K., Turner, S., Waite, A., and Zeldis, J.: A mesoscale phytoplankton bloom in the polar Southern Ocean stimulated by iron fertilization, Nature, 315, 612-617, doi:10.1038/35037500, 2000.

Boyd, P. W., Strzepek, R., Chiswell, S., Chang, H., DeBruyn, J. M., Ellwood, M., Keenan, S., King, A. L., Maas, E. W., Nodder, S., Sander, S. G., Sutton, P., Twining, B. S., Wilhelm, S. W., and Hutchins, D. A.: Microbial control of diatom bloom dynamics in the open ocean, Geophys. Res. Lett., 39, 1-6, doi:10.1029/2012GL053448, 2012.

Cavagna, A. J., Fripiat, F., Elskens, M., Dehairs, F., Mangion, P., Chirurgien, L., Closset, I., Lasbleiz, M., Flores-Leiva, L., Cardinal, D., Leblanc, K., Fernandez, C., Lefèvre, D., Oriol, L., Blain, S., and Quéguiner, B.: Biological productivity regime and associated $\mathrm{N}$ cycling in the vicinity of Kerguelen Island area, Southern Ocean, Biogeosciences Discuss., 11, 18073-18104, doi:10.5194/bgd-11-18073-2014, 2014.

Closset, I., Lasbleiz, M., Leblanc, K., Quéguiner, B., Cavagna, A.J., Elskens, M., Navez, J., and Cardinal, D.: Seasonal evolution of net and regenerated silica production around a natural $\mathrm{Fe}$ fertilized area in the Southern Ocean estimated with $\mathrm{Si}$ isotopic approaches, Biogeosciences, 11, 5827-5846, doi:10.5194/bg-115827-2014, 2014.

d'Ovidio, F., Della Penna, A., Trull, T. W., Nencioli, F., Pujol, I., Rio, M. H., Park, Y.-H., Cotté, C., Zhou, M., and Blain, S.: The biogeochemical structuring role of horizontal stirring: Lagrangian perspectives on iron delivery downstream of the Kerguelen plateau, Biogeosciences Discuss., 12, 779-814, doi:10.5194/bgd-12-779-2015, 2015.

Fourquez, M., Obernosterer, I., and Blain, S.: A method for the use of the radiotracer $55 \mathrm{Fe}$ for microautoradiography and CARDFISH of natural bacterial communities, FEMS Microbiol. Lett., 337, 132-139, doi:10.1111/1574-6968.12022, 2012.

Fourquez, M., Devez, A., Schaumann, A., Guéneuguès, A., Jouenne, T., Obernosterer, I., and Blain, S.: Effects of iron limitation on growth and carbon metabolism in oceanic and coastal heterotrophic bacteria, Limnol. Oceanogr., 59, 349-360, doi:10.4319/lo.2014.59.2.0349, 2014.

Fukuda, R., Ogawa, H., Nagata, T., and Koike, I.: Direct determination of carbon and nitrogen contents of natural bacterial assemblages in marine environments, Appl. Environ. Microb., 64, 3352-3358, 1998. 
Granger, J. and Price, N. M.: The importance of siderophores in iron nutrition of heterotrophic marine bacteria, Limnol. Oceanogr., 44, 541-555, doi:10.4319/lo.1999.44.3.0541, 1999.

Hassler, C. S., Alasonati, E., Mancuso Nichols, C. A., and Slaveykova, V. I.: Exopolysaccharides produced by bacteria isolated from the pelagic Southern Ocean - Role in Fe binding, chemical reactivity, and bioavailability, Mar. Chem., 123, 88-98, doi:10.1016/j.marchem.2010.10.003, 2011a.

Hassler, C. S., Schoemann, V., Nichols, C. M., Butler, E. C. V., and Boyd, P. W.: Saccharides enhance iron bioavailability to Southern Ocean phytoplankton, P. Natl. Acad. Sci. USA, 108, 10761081, doi:10.1073/pnas.1010963108, 2011b.

Hopkinson, B. M. and Barbeau, K. A.: Iron transporters in marine prokaryotic genomes and metagenomes, Environ. Microbiol., 14, 114-28, doi:10.1111/j.1462-2920.2011.02539.x, 2012.

Hudson, R. J. M. and Morel, F. M. M.: Distinguishing between extra- and intracellular iron in marine phytoplankton, Limnol. Oceanogr., 34, 1113-1120, doi:10.4319/lo.1989.34.6.1113, 1989.

King, A. L., Sañudo-Wilhelmy, S. A., Boyd, P. W., Twining, B. S., Wilhelm, S. W., Breene, C., Ellwood, M. J., and Hutchins, D. A.: A comparison of biogenic iron quotas during a diatom spring bloom using multiple approaches, Biogeosciences, 9, 667-687, doi:10.5194/bg-9-667-2012, 2012.

Kirchman, D. L., Meon, B., Cottrell, M. T., Hutchins, D. A., Weeks, D., and Bruland, K. W.: Carbon versus iron limitation of bacterial growth in the California upwelling regime, Limnol. Oceanogr., 45, 1681-1688, doi:10.4319/lo.2000.45.8.1681, 2000.

Lasbleiz, M., Leblanc, K., Blain, S., Ras, J., Cornet-Barthaux, V., Hélias Nunige, S., and Quéguiner, B.: Pigments, elemental composition $(\mathrm{C}, \mathrm{N}, \mathrm{P}$, and $\mathrm{Si}$ ), and stoichiometry of particulate matter in the naturally iron fertilized region of Kerguelen in the Southern Ocean, Biogeosciences, 11, 5931-5955, doi:10.5194/bg-115931-2014, 2014.

Litchman, E., Klausmeier, C. A., and Bossard, P.: Phytoplankton nutrient competition under dynamic light regimes, Limnol. Oceanogr., 49, 1457-1462, 2004.

Madsen, E. L.: Microorganisms and their roles in fundamental biogeochemical cycles, Curr. Opin. Biotech., 22, 456-64, doi:10.1016/j.copbio.2011.01.008, 2011.

Maldonado, M. T., Boyd, P. W., LaRoche, J., Strzepek, R. F., Waite, A., Bowie, A. R., Croot, P. L., Frew, R. D., and Price, N. M.: Iron uptake and physiological response of phytoplankton during a mesoscale Southern Ocean iron enrichment, Limnol. Oceanogr., 46, 1802-1808, doi:10.4319/lo.2001.46.7.1802, 2001.

Marchetti, A., Parker, M. S., Moccia, L. P., Lin, E. O., Arrieta, A. L., Ribalet, F., Murphy, M. E. P., Maldonado, M. T., and Armbrust, E. V.: Ferritin is used for iron storage in bloom-forming marine pennate diatoms, Nature, 457, 467-470, doi:10.1038/nature07539, 2009.

Marie, D., Partensky, F., Jacquet, S., and Vaulot, D.: Enumeration and cell cycle analysis of natural populations of marine picoplankton by flow cytometry using the nucleic acid stain SYBR Green I, Appl. Environ. Microb., 63, 186-193, 1997.

Martin, J. H.: Glacial interglacial $\mathrm{CO}_{2}$ change: the iron hypothesis, Paleoceanography, 5, 1-13, doi:10.1029/PA005i001p00001, 1990.
Massana, R. and Logares, R.: Eukaryotic versus prokaryotic marine picoplankton ecology, Environ. Microbiol., 15, 1254-1261, doi:10.1111/1462-2920.12043, 2012.

Mills, M. M., Moore, C. M., Langlois, R., Milne, A., Achterberg, E. P., Nachtigall, K., Lochte, K., Geider, R. J., and La Roche, J.: Nitrogen and phosphorus co-limitation of bacterial productivity and growth in the oligotrophic subtropical North Atlantic, Limnol. Oceanogr., 53, 824-834, doi:10.4319/lo.2008.53.2.0824, 2008.

Nielsdóttir, M. C., Bibby, T. S., Moore, C. M., Hinz, D. J., Sanders, R., Whitehouse, M., Korb, R., and Achterberg, E. P.: Seasonal and spatial dynamics of iron availability in the Scotia Sea, Mar. Chem., 130-131, 62-72, doi:10.1016/j.marchem.2011.12.004, 2012.

Obernosterer, I., Christaki, U., Lefevre, D., Catala, P., Vanwambeke, F., and Lebaron, P.: Rapid bacterial mineralization of organic carbon produced during a phytoplankton bloom induced by natural iron fertilization in the Southern Ocean, Deep-Sea Res. Pt. II, 55, 777-789, 2008.

Obernosterer, I., Fourquez, M., and Blain, S.: Fe and C co-limitation of heterotrophic bacteria in the naturally fertilized region off Kerguelen Islands, Biogeosciences Discuss., 11, 15733-15752, doi:10.5194/bgd-11-15733-2014, 2014.

Pollard, R. T., Salter, I., Sanders, R. J., Lucas, M. I., Moore, C. M., Mills, R. A., Statham, P. J., Allen, J. T., Baker, A. R., Bakker, D. C. E., Charette, M. A., Fielding, S., Fones, G. R., French, M., Hickman, A. E., Holland, R. J., Hughes, J. A., Jickells, T. D., Lampitt, R. S., Morris, P. J., Nédélec, F. H., Nielsdóttir, M., Planquette, H., Popova, E. E., Poulton, A. J., Read, J. F., Seeyave, S., Smith, T., Stinchcombe, M., Taylor, S., Thomalla, S., Venables, H. J., Williamson, R., and Zubkov, M. V.: southern Ocean deep-water carbon export enhanced by natural iron fertilization, Nature, 457, 577-580, doi:10.1038/nature07716, 2009.

Quéguiner, B.: Iron fertilization and the structure of planktonic communities in high nutrient regions of the Southern Ocean, Deep-Sea Res. Pt. II, 90, 43-54, doi:10.1016/j.dsr2.2012.07.024, 2013.

Quéroué, F., Sarthou, G., Planquette, H. F., Bucciarelli, E., Chever, F., van der Merwe, P., Lannuzel, D., Townsend, A. T., Cheize, M., Blain, S., d'Ovidio, F., and Bowie, A. R.: High variability of dissolved iron concentrations in the vicinity of Kerguelen Island (Southern Ocean), Biogeosciences Discuss., 12, 231-270, doi:10.5194/bgd-12-231-2015, 2015.

Sarthou, G., Vincent, D., Christaki, U., Obernosterer, I., Timmermans, K. R., and Brussaard, C. P. D.: The fate of biogenic iron during a phytoplankton bloom induced by natural fertilisation: impact of copepod grazing, Deep-Sea Res. Pt. II, 55, 734-751, doi:10.1016/j.dsr2.2007.12.033, 2008.

Strzepek, R. F. and Harrison, P. J.: Photosynthetic architecture differs in coastal and oceanic diatoms, Nature, 403, 689-692, doi:10.1038/nature02954, 2004.

Strzepek, R. F., Hunter, K. A., Frew, R. D., Harrison, P. J., and Boyd, P. W.: Iron-light interactions differ in Southern Ocean phytoplankton, Limnol. Oceanogr., 57, 1182-1200, doi:10.4319/lo.2012.57.4.1182, 2012.

Strzepek, R. F., Maldonado, M. T., Higgins, J. L., Hall, J., Safi, K., Wilhelm, S. W., and Boyd, P. W.: Spinning the "Ferrous Wheel": the importance of the microbial community in an iron budget 
during the FeCycle experiment, Global Biogeochem. Cy., 19, 114, doi:10.1029/2005GB002490, 2005.

Sunda, W. G. and Huntsman, S. A.: Iron uptake and growth limitation in oceanic and coastal phytoplankton, Mar. Chem., 50, 189-206, doi:10.1016/0304-4203(95)00035-P, 1995.

Sunda, W. G. and Huntsman, S. A.: Interrelated influence of iron, light and cell size on marine phytoplankton growth, Nature, 390, 389-392, doi:10.1038/37093, 1997.

Tang, D. and Morel, F. M. M.: Distinguishing between cellular and Fe-oxide-associated trace elements in phytoplankton, Mar. Chem., 98, 18-30, doi:10.1016/j.marchem.2005.06.003, 2006.

Tortell, P. D., Maldonado, M. T., and Price, N. M.: The role of heterotrophic bacteria in iron-limited ocean ecosystems, Nature, 383, 330-332, doi:10.1038/383330a0, 1996.
Toulza, E., Tagliabue, A., Blain, S., and Piganeau, G.: Analysis of the global ocean sampling (GOS) project for trends in iron uptake by surface ocean microbes, edited by: Rodriguez-Valera, F., PLoS One, 7, e30931, doi:10.1371/journal.pone.0030931, 2012.

Trull, T. W., Davies, D. M., Dehairs, F., Cavagna, A.-J., Lasbleiz, M., Laurenceau-Cornec, E. C., d'Ovidio, F., Planchon, F., Leblanc, K., Quéguiner, B., and Blain, S.: Chemometric perspectives on plankton community responses to natural iron fertilisation over and downstream of the Kerguelen Plateau in the Southern Ocean, Biogeosciences, 12, 1029-1056, doi:10.5194/bg-121029-2015, 2015. 